\title{
Determinants of Technical Inefficiency of Saccos in Kenya: A Net Operating Cash Flows Output Slack Analysis
}

\author{
Leonard Rang'ala Lari ${ }^{1} \nless$ \\ Philip Mulama NYangweso ${ }^{2}$ \\ Lucy Jepchoge Ronos \\ ${ }_{1,2, s}$ School of Business and Economics, Moi University-Kenya
}

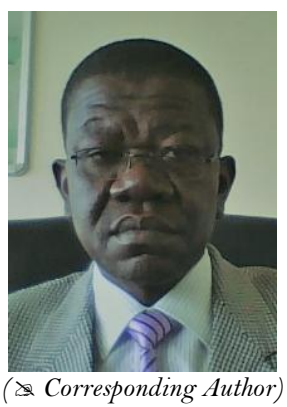

\begin{abstract}
Purpose: The purpose of this study was to evaluate the determinants of technical inefficiency of Saccos in Kenya. Methodology: The explanatory research design was utilized. The financial statements data was collected from a census of 46 audited deposit taking Saccos and methods used included estimation of technical inefficiency by employing a non-parametric DEA method while the second step concerned determination of inefficiency using parametric SFA. The log truncated panel data was used for a period of 8 years (2007-2014). Result: All the predictors jointly influence inefficiency and are significant except for prime regressors given NOCF slack as hypothesized in agency, efficiency and intermediation theories. NOCF slack regression reflects lack of managerial influence as indicated by Gamma (1.13E-23) while DEA result of all Saccos indicated 0.976 mean efficiency. Contribution to policy and practice: The NPTA, CA and FI predictors had significant influence on pure technical inefficiency, thus apt for decision making.
\end{abstract}

Keywords: Saccos in Kenya, Technical inefficiency, Net operating cash flows (NOCF) Output slack.

Citation | Leonard Rang'ala Lari; Philip Mulama NYangweso; Lucy Jepchoge Rono (2017). Determinants of Technical Inefficiency of Saccos in Kenya: A Net Operating Cash Flows Output Slack Analysis. Asian Journal of Economics and Empirical Research, 4(2): $49-60$.

History:

Received: 25 August 2017

Revised: 15 September 2017

Accepted: 21 September 2017

Published: 27 September 201

Licensed: This work is licensed under a Creative Commons

Attribution 3.0 License (cc)

Publisher:Asian Online Journal Publishing Group
Contribution/Acknowledgement: All authors contributed to the conception and design of the study.

Funding: This study received no specific financial support

Competing Interests: The authors declare that they have no conflict of interests.

Transparency: The authors confirm that the manuscript is an honest, accurate, and transparent account of the study was reported; that no vital features of the study have been omitted; and that any discrepancies from the features of the study have been omitte
study as planned have been explained.

Ethical: This study follows all ethical practices during writing.

\section{Contents}

1. Introduction 50

2. Literature Review and Background of the Study 50

3. Research Methodology . .52

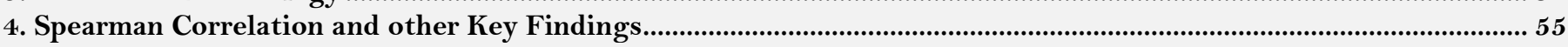

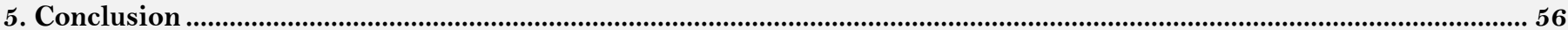

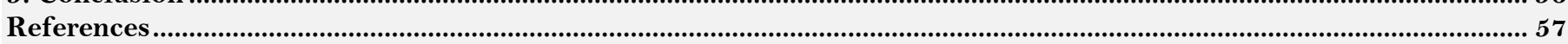




\section{Introduction}

The efficiency of an organization is an overriding aspect in finance. A well-managed savings and credit cooperative society is expected to increase the members' interest. Since independence, the Kenya savings and credit co-operatives societies'(or Saccos) sub-sector has undergone a series of liberalizations and prudential regulation aimed at improving its relative act or efficiency (Wanyama, 2009). This study seeks to find out the determinants of inefficiency given the net operating cash flow slack (inefficiency) as a dependent variable over a period of two eras using both data envelopment analysis(a linear programming approach) and stochastic frontier analysis methods.

The co-operatives development regulation era in Kenya involved enactment of prudential regulation of Saccos through the Saccos Act, 2008 which legally commenced in September 2009 and gave birth to Sacco Societies Regulatory Authority or SASRA with effect from October 2009 (SSA, 2008; MOCDM, 2013). Basically the preregulation era covered period 2010 and before.

Kenya Saccos have high urge for shifting from savings and credit co-operatives to credit and savings cooperatives that is, they actually bend towards sourcing for external funds than relying on equity funding. Capital inadequacy and insolvency risks are key factors influencing performance of deposit taking Saccos (or FOSA) in Kenya (Kivuvo and Olweny, 2014). This behavior scores them well as candidates of capital rationing. The shifting appetite to credit and savings Saccos come at an expensive interest charges from the lenders as the borrowed funds or credit facilities are meant for onward affordable lending to Saccos' members. According to SASRA (2011) Saccos in Kenya total borrowings from banks in 2010 was estimated at Kshs. 15 billion compared to Kshs. 5.6 billion in 2011. Thus the sector is key financial channel in fostering access to credit.

On the international front, the Regulatory Authorities and Standards Setting Committees have been able to come up with acceptable information on the financial institutions' efficient operations and risk management criteria (Cooper et al., 2007). World Council of Credit Unions is one similar body that offers related services. Caprio et al. (2003) in their study in 44 countries, postulate that insignificant influence is experienced by banks due to regulation and supervision.

\section{Literature Review and Background of the Study}

Brealey and Myers (1981) postulated that rationing of a firm's capital in more than one period call for application of linear programming or net present value methods as a capital budgeting decision making techniques instead of other methods such as marginal rate of return which depict prominence of linear programming in the field of finance theory. This study adopted DEA approach which is linear programming oriented based on a capital rationing argument, since the Saccos' external loan capital demand tend to fluctuate periodically (SASRA, 2011).

Efficiency is a subset of performance (Ozcan, 2008). An efficient organization identification assist in identifying the managers' rewards and the kind of good practices employed or which can be copied by inefficient firms in the industry. Adeptness also aid in identifying profitable areas of organizations to invest their assets (Healy, 1988). An efficient measurement system is able to identify optimal resources allocation besides setting of targets.

The inefficiency or efficiency measurement helps commercial and non-commercial entities in identification of best practice, identification of poor practice, in setting targets, in resource allocation and in monitoring efficiency changes periodically (Beasley, 1996). However, Barus et al. (2017) argues that financial performance of Saccos in Kenya is not significantly affected by management efficiency.

Studies have indicated that co-operative banks future in the long run is unknown as they will completely transform to banks, merge or just die, Zvi (1998). This chain of events is likely to impact negatively on the steady or focused efficiency growth of Saccos. A question that then arises is: do co-operatives transformations to banks or FOSA exist for long term benefit of members? Zvi (1998) states that credit co-operatives around the world do not exist to allocate credit to their members as only $30 \%-70 \%$ is allocated as loans and the rest is either in cash and cash equivalent.

A study by Johnson and Nino-Zarazua (2008) has shown that in Kenya 12.8\% of the population save with Saccos and $4.1 \%$ borrow from them. In addition, Saccos in Kenya are principally either based on common bonds of farming or employment (Johnson and Nino-Zarazua, 2008). It is also worth noting that in Africa South of the Sahara, Kenyan Saccos movement has the second largest number of Saccos following Ethiopia (Woccu, 2009). For instance, in March 2013, the number of Saccos in Tanzania were 5,559 (Magali, 2014) while in Kenya the total number of registered Saccos were estimated at about 7,500 in August 2013 (SASRA, 2013).

The efficiency of co-operatives during the era of economic liberalization (1980s up to 2004) was initially absolutely poor due to the government modus operandi (Wanyama, 2009). However since the start of the second era period; co-operative development in the country is still not well understood. This is because there are a few studies in the area of co-operatives since 1990 (Evans, 2002; Petrie, 2002; Emerson and Wiren, 2005). Further, these studies are basically based on absolute performance measures (such as increase in loans, increase in membership levels of delinquent loans, and growth in number of co-operatives) and interview responses from the stakeholders. The situation is slowly changing as other research are now coming up especially based on ratios, efficiency and multiple regression such as (Tesfamariam et al., 2013; Kivuvo and Olweny, 2014; Mirie, 2014; Marwa and Aziakpono, 2015).

During the pre-regulation era in 2009, the world experienced a financial crisis that affected the efficiency of financial institutions over the period and this was amenably reflected in the levels of macro-economic indicators including GDP. In 2009, for instance the global economy contracted by negative 0.6\% (IMF, 2012) while in 2011 the country also experienced a down turn in the economy due to high fluctuation of the Kenya shilling against the hard foreign currencies (SASRA, 2011). In addition, the GDP percent change rate fluctuated to an average of $5.13 \%$ in 2012 before rising again to a mean of $5.62 \%$ in 2013 (IMF, 2014).

The down turn in an economy impairs the efficiency of commercial enterprises than it does to co-operatives. Co-operatives have shown their ability to provide services to their members even during the financial crisis. However, in developing countries of Africa the co-operatives' resilience to financial crisis is not strong and this coupled with the internal political impact or mismanagement within co-operatives means, the crisis gets worse (Wanyama et al., 2009). This then raises a corporate governance or integrity problem in co-operative movement 
that was catered for, to some extent, in this study through the introduction of the number of women on the board predictor variable.

According to prior studies, there is a conflicting result on effect of gender diversity on the boards. Adams and Ferreira (2008) argue that on average the presence of both gender on the boards in companies having no takeover prevention mechanism do experience inefficiency. On the contrary, Higgs (2003) postulate that performance improvement result from gender diversity in the board room while Gompers et al. (2003) conclude that gender is a good performance contributor in organizations with non-strong shareholder rights.

The latest liberalization of co-operatives movement is in the area of devolution of co-operatives regulation from the national level to county levels as enshrined in the Constitution of Kenya 2010 (COK, 2010; MOCDM, 2013). These changes are aimed at enhancing efficiency. However, despite the existence of the prudential regulations, the deposit taking Saccos have continued to reveal mixed levels of management practices or inefficiency (SASRA, 2013). In addition, a study by Chavez (2006) indicates that the Kenya Sacco sub-sector reflects a seriously weak financial performance position that is pervasive.

\subsection{Theoretical Review}

This research was guided by the theory of agency and the financial institutions efficiency measurement theories; more precisely, the intermediation theory. Other discussed models relevant to this research are the financial institutions' prudential monitoring standards. However, the regulator of deposit taking Saccos in Kenya advocates for the adoption of Camels Prudential Reporting Standards (Kivuvo and Olweny, 2014). Further, this study utilized the BCC analysis based on inefficient results of DEA as dependent variables (Banker et al., 1984) which were used to identify the variables that best measure the pure technical inefficiency of the Saccos by running a truncated-normal regression given a census of 46 deposit taking Saccos that had by then attained the FOSA operation requirements.

\subsection{Statement of the Problem}

The co-operatives sector in Kenya has gone through a historical development process known for inefficiency. The inefficiency was more prevalent during the liberalization period (Wanyama, 2009). As a result, the need for regulation and inefficiency understanding becomes necessary to ensure the stability of Saccos' sub-sector and guaranteed efficiency. This study is also an addition to ongoing inefficiency of Saccos' research in the Kenyan context.

A few past researchers in Kenya have studied Saccos without utilizing SFA and identifying benchmark Saccos , they based on performance: (Olando et al., 2012; Karanja, 2013; Njagi et al., 2013; Nyambere, 2013; Okibo and Karagu, 2014; Barus et al., 2017). These studies ignored the aspect of efficiency measurement yet Saccos unlike other commercial enterprises exist for purposes of service delivery to members and therefore are not highly profit oriented. A more recent study by Mirie (2014) indicates Saccos' efficiency in Kenya being within a range of 0.56 and 1.0. However, it failed to consider other specific variables of efficiency measurement such as the economic indicators, gender diversity on Saccos' boards, and net profit to total assets ratio beside the extent of management influence on Saccos' inefficiency. Marwa and Aziakpono (2015) studied technical and scale efficiency of Saccos in Tanzania using DEA and concluded that on average majority of Saccos scored 0.48 pure technical inefficiency and at least $75 \%$ of Saccos exhibited an increasing returns to scale. A study by Kipesha (2012) arrived at an efficiency of between 0.145 and 0.69 for the Tanzanian micro finance bodies. Similar researches in banking industry in subSaharan Africa opine that technical efficiency falls between 0.6 and 0.9 (Moffat, 2008; Kamau, 2011).

According to Tesfamariam et al. (2013) efficiency of rural Saccos in Ethiopia indicated that efficiency is affected by both location and size of Saccos. They also opine that on average efficiency ranged between 0.213 and 0.259 for small Saccos, while larger Saccos recorded higher efficiency compared to smaller ones. The study like Magali (2014) in Kenya also suggested future study in the area of Saccos' technical efficiency using the SFA.

Magali (2014) concludes that there is no prior studies on Saccos in East Africa that have assessed the influence of regulation on Saccos performance while at the same time considering the impact of rural and urban areas' location of Saccos on performance. He further argues that scholars should extend to econometrics to expand Saccos modeling. A few studies such as Marwa and Aziakpono (2015) in Tanzania, and Tesfamariam et al. (2013) in Ethiopia, have researched on the efficiency of Saccos in the African continent.

Considering the above mentioned gap of prior studies, this study examined whether Saccos were more inefficient during regulation era than pre-regulation era. The stars Saccos were also identified. Essentially this study assessed the determinants of inefficiency of FOSA. Specifically the pure technical efficiency (a cost-efficiency measure) model was utilized (Coelli et al., 1997).

The creation of SASRA as a regulator of Saccos has been necessitated by the challenges of a liberalized economy. The question that arises then is: to what extent has the Saccos' market become efficient? These facts then point to the need to measure and determine the Kenyan Saccos' pure technical inefficiency or efficiency. This study sets deliberate standards on how Saccos in Kenya can be monitored and peers emulated to ensure efficiency in their operations.

\subsection{The General Objective}

The general objective of this study is to establish the determinants of technical inefficiency of deposit taking Saccos in Kenya, given a net operating cash flow slack (an output inefficiency) as a dependent variable.

\subsection{The Specific Objectives}

The specific objectives of this study are as follows:

1. Measure the extent of managerial inefficiency over the pre-regulation and regulation eras.

2. Establish the effect of macro-economic variables on the Saccos' net operating cash flows output inefficiency. 
3. Determine the effect of Saccos' specific predictor variables on Saccos' net operating cash flows output inefficiency.

4. Determine the inefficiency mean scores over the two regulation and pre-regulation eras.

\subsection{Research Hypotheses}

The study also tests the hypotheses that:

1. $\mathrm{H}_{01}$ : The Saccos operation is not influenced by managerial influence (inefficiency) as measured by Gamma $(\Upsilon)$ over the two eras.

2. $\mathrm{H}_{02}$ : There is no strong relationship between the Saccos' macro-economic variables and net operating cash flows output inefficiency dependent variable.

3. $\mathrm{H}_{03}$ : There is no strong relationship between the Saccos' specific independent variables and net operating cash flows output inefficiency dependent variable.

4. $\mathrm{H}_{04}$ : Pre-regulation and regulation eras have the same population of inefficiency mean scores.

\subsection{The Concept of Technical Inefficiency}

The conceptual framework model in Figure 1 reflects the dependent variables derived from the output inefficiencies (specifically, the NOCF slack), and independent variables relationship. The frontier preliminary analysis involved determination of correlation between each of the Saccos' variance regressors and prime regressors, and if a high correlation is discovered, such specific independent variable (prime regressor) is removed from the second or final stage regression process. However, no variable was removed and this estimation was also internalized within the Stata14.1. Further, prime regressors are also assumed to be measurement errors free (Cooper et al., 2007).

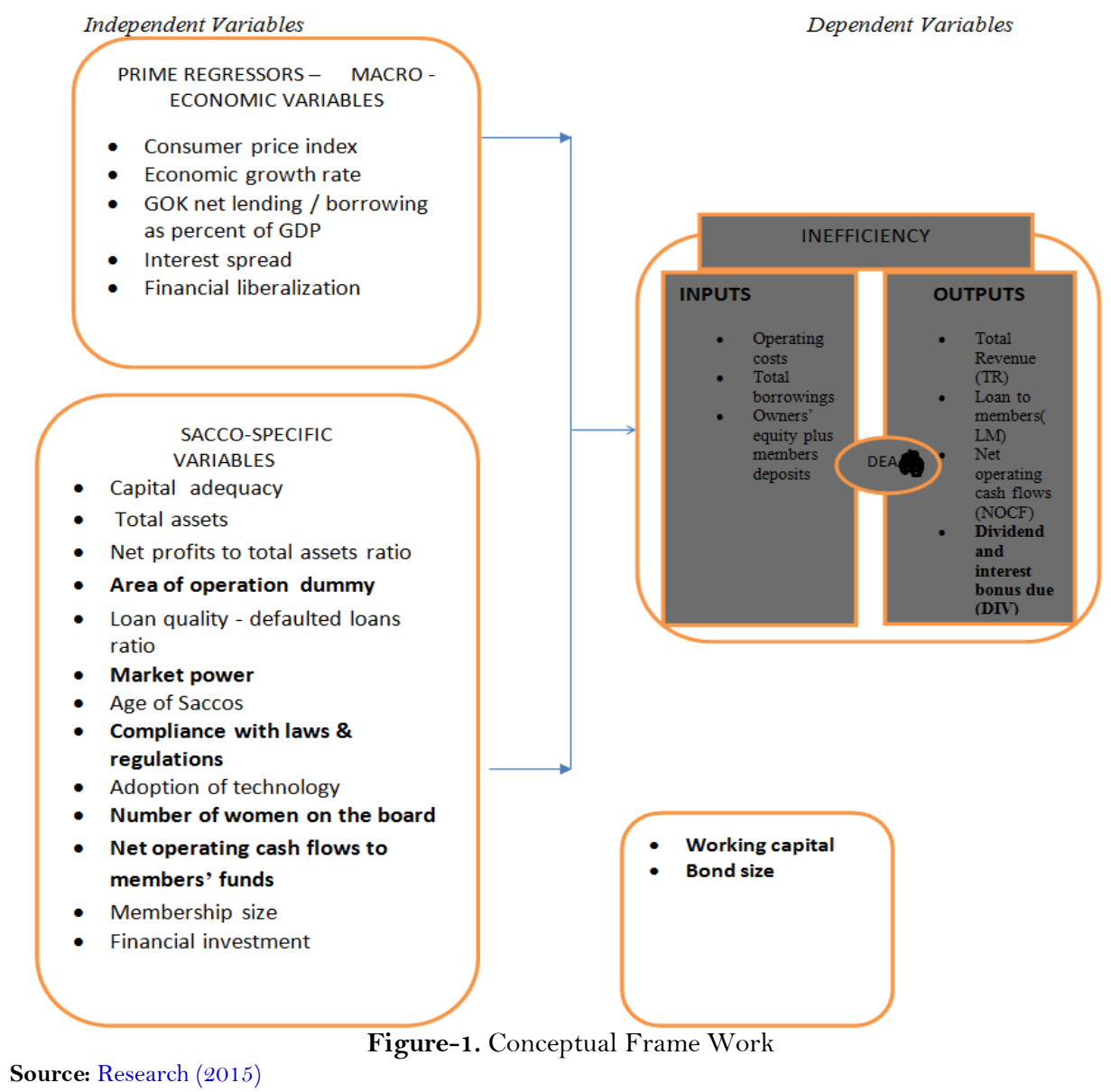

\section{Research Methodology}

\subsection{Design}

This explanatory study used a balanced panel data. The explanatory study research design was employed in soliciting for secondary information from the audited annual reports and websites of the regulators on determinants of Saccos' inefficiency in Kenya. This study utilized a second stage data envelopment analysis by subjecting the resultant data to SFA. An econometric approach in estimation of Saccos' inefficiency determinants was utilized since SFA stipulates the functional form of cost or production frontier (Cummins and $\mathrm{Zi}, 1998$ ). The panel data has benefit of assisting in studying the behavior of each Sacco on cross-sectional and time-series or year basis (Ongore and Kusa, 2013). In addition, this study utilized a census technique whereby 46 licensed Saccos under the regulator's control within the two periods of study running from 2007 to 2010, and 2011 to 2014(a span of 8 years) were picked.

\subsection{Model Specification}

The estimation of inefficiency was carried out utilizing the Cobb-Douglas cost frontier cross- sectional panel data of Saccos over two periods. Truncated-normal distribution was assumed Coelli et al. (2005) and Cooper et al. (2011). Stata 14.1 was used to decompose errors (Jondrow et al., 1982; Pascoe et al., 2003). The SFA was based on Cobb-Douglas logarithmic model Iny ${ }^{*}=\beta_{0}+\sum_{1}^{k} \beta \mathrm{r}_{\mathrm{InZ}} \mathrm{kjt}_{\mathrm{j}}+\mathrm{V}_{\mathrm{rjt}}+\mathrm{U}_{\mathrm{rjt}}$, where: $\beta_{\mathrm{r}}$ is the frontier deterministic component, $\mathrm{V}_{\mathrm{rjt}}$ is stochastic part and $\mathrm{U}_{\mathrm{rjt}}$ presents the shortfall observed individual fails to hit the optimum 
(frontier), $\mathrm{j}(\mathrm{j}=1, \ldots, \mathrm{n})$ is the cross-sectional identifier, $\mathrm{t}(\mathrm{t}=1, \ldots, \mathrm{t})$ is time identifier, $\mathrm{y}^{*}$ is the first stage optimal $\operatorname{slack(normalized)~in~output~} \mathrm{r}$ of $\mathrm{DMU}_{\mathrm{j}}, \beta$ o is the intercept of output slack equation, 'In' is natural logarithm, and $\mathrm{Z}$ has $\mathrm{k}(\mathrm{k}=1, \ldots, \mathrm{k})$ observable environmental factors (Battese and Coelli, 1995).

\subsection{DEA Result}

The study examined the inefficiency and efficiency census of 46 Saccos using a non-parametric variable return to scale (VRS) - BCC or technical efficiency model. The model utilized was output oriented whereby the output included: total revenue, loans to members, net operating cash flows, and divided plus interest on members deposits while inputs were: operating costs, total borrowings and owners' equity plus members deposits. The panel data model utilized using Stata DEA software was derived from 368 observations while technical efficiency was measured on scale of o up to a maximum of 1. DEA result indicated that a total of 24 out of 46 Saccos were strongly efficient and exhibited zero slacks across all output variables and this was attributed to net operating cash flows reported for the corresponding years.

\subsection{Output Description}

Table 1 presents the mean output as expressed in TR(total revenue slack), LM(loan to members slack), NOCF(net operating cash flows slack), and DIV(dividend slack) in Kshs.Million for years 2007 to 2014. As reflected in the table 3.1 the mean TR, LM, NOCF, DIV for the Saccos sub-sector (FOSA) was 427, 2234, 1038, and 148 respectively. The overall mean score as a percentage of the Saccos' sub-sector sum was $0.18 \%$ across all outputs.

Table-1. Eight Years Mean Outputs of Saccos in Kenya

\begin{tabular}{|c|c|c|c|c|}
\hline \multicolumn{5}{|c|}{ Eight Years Mean Outputs of Saccos in Kenya } \\
\hline & TR & LM & NOCF & DIV \\
\hline Mean score & 427 & 2234 & 1038 & 148 \\
\hline Standard Deviation & 1114 & 6720 & 1380 & 596 \\
\hline Mean as a \% of Industry Sum & 0.18 & 0.18 & 0.18 & 0.18 \\
\hline Observations & 368 & 368 & 368 & 368 \\
\hline
\end{tabular}

\subsection{Descriptive Statistics}

The descriptive statistics in Table 2 presents specific variables that determine the inefficiency of Saccos in Kenya. As reflected in the Table 2, the mean capital adequacy of Saccos in Kenya was $21 \%$. The percentage is above $10 \%$ set by SASRA (SSR, 2010). This indicates that Saccos in Kenya running FOSA hold more capital than required. This was an indication that Saccos running FOSA in Kenya were risk averse and in return earn less profit. On the contrary the ratio of net profit to total assets is high at $22 \%$, an indication of mixed result pointing to the direction of inefficiency (Brown, 2006). The market power of $2 \%$ is far below $70 \%$ standard market share that indicates a few firms being in control of an industry (Ogebe et al., 2013). Further, the average women on the board stood at $20 \%$ with standard deviation of $12 \%$. This is a low number and has little influence on Saccos' inefficiency (Higgs, 2003).

The Table 2 also reflect mean defaulted loans ratio being 3\% which is below $4 \%$ according to census research on Saccos in Meru County Kenya (Olando et al., 2012). This is an indication that the regulator role has played an impact in reducing the default risks to lower percentage and may point to the direction that in this sub-sector, loan guarantors carry next to $97 \%$ burden in case of any default thus lowering LP effect on inefficiency. According to Brown and O'Connor (1999) higher default rate lowers the relative efficiency of a money market. The average age of Saccos was shown as 27 years with a standard deviation of 9 years, a reflection of a young industry. Magali (2014) posit that age and size are correlated in the same direction and that a rise in age of a small firm has a positive relation with efficiency.

Table-2. Descriptive Statistics of Predictor Variables

Descriptive Statistics of Predictor Variables

\begin{tabular}{|c|c|c|c|c|c|c|c|c|c|c|}
\hline \multicolumn{11}{|c|}{ Descriptive Statistics of Predictor Variables } \\
\hline Variables & CA & Bond & NPTA & MP & $\mathbf{W}$ & MS & LP & Age-Yrs. & GOKLB & Age-Yrs. \\
\hline Mean & 0.21 & 5.33 & 0.22 & 0.02 & 0.20 & 21245 & 0.03 & 27.07 & 2.72 & 27.07 \\
\hline $\begin{array}{c}\text { Standard } \\
\text { Deviation }\end{array}$ & 0.15 & 10.78 & 0.02 & 0.04 & 0.12 & 36063 & 0.09 & 9.30 & 1.37 & 9.30 \\
\hline$\overline{\text { Observations }}$ & 368 & 368 & 368 & 368 & 368 & 368 & 368 & 368 & 368 & 368 \\
\hline
\end{tabular}

\subsection{Operationalization of the Study Variables}

The study measurements used to operationalize the study specific variables are as indicated in Table 3. 
Table-3. Study Variables

\begin{tabular}{l|l}
\hline Study Variable & Measurement \\
\hline Capital adequacy(CA) & Core capital to total assets \\
\hline Total assets(TA) & Natural log of total assets \\
\hline NPTA & Net profit to total assets \\
\hline Area of operation $(\mathrm{AO})$ & Dummies 1-City ; -Urban \\
\hline Loan quality(LP) & Loans provision \\
\hline Market power(MP) & Sacco deposit to total FOSA deposits \\
\hline Age & Number of years in operation \\
\hline CLR & Compliance with regulations(average scores) \\
\hline Atech & Computerization expenditures \\
\hline W & Fraction of women on the board \\
\hline NCFM & Net operating cash flows to members funds \\
\hline MS & Number of members \\
\hline WC & Current assets less current liabilities \\
\hline Bond & Size of contributing common bond employers \\
\hline FI & Financial investments total amount \\
\hline Source Research $(0015)$ &
\end{tabular}

Source: Research (2015)

\subsection{Model Testing and Random Effects Estimation}

The study test carried out to ensure that the data fits the linear regression assumptions include:

\subsubsection{Normality Test}

The study tested for normality using Shapiro-Francia W test as the observations were less than 5000 and greater than 10 under log normality condition (Stata, 2015). The result obtained is as shown in Table 4 which indicates that only two variables reflected p-values greater than 0.05 thus a possibility of heteroscedasticity. The data used also underwent natural logarithm transformation.

Table-4. Testing Study Variables for Normality

\begin{tabular}{l|l|l|l|l}
\hline & Shapiro-Francia & W test for normal data & & \\
\hline Variable & $\mathrm{W}^{\prime}$ & $\mathrm{V}^{\prime}$ & $\mathrm{Z}$ & Prob. $>\mathrm{z}$ \\
\hline Age & 0.89443 & 29.112 & 7.251 & 0.00001 \\
\hline $\mathbf{C a}$ & 0.99163 & 2.307 & 1.798 & 0.03608 \\
\hline $\mathbf{T a}$ & 0.98818 & 3.259 & 2.541 & 0.00553 \\
\hline Npta & 0.84112 & 43.814 & 8.13 & 0.00001 \\
\hline Ao & 1 & 0 & -58.997 & 1 \\
\hline Lp & 0.74358 & 70.711 & 9.16 & 0.00001 \\
\hline Mp & 0.93325 & 18.406 & 6.265 & 0.00001 \\
\hline Clr & 0.70719 & 80.744 & 9.445 & 0.00001 \\
\hline Atech & 0.68281 & 87.468 & 9.617 & 0.00001 \\
\hline W & 0.98012 & 5.482 & 3.66 & 0.00013 \\
\hline Ncfma & 0.34704 & 180.06 & 11.171 & 0.00001 \\
\hline Ms & 0.99448 & 1.522 & 0.904 & 0.1831 \\
\hline Cpi & 0.95686 & 11.896 & 5.326 & 0.00001 \\
\hline Gdp & 0.61534 & 106.072 & 10.032 & 0.00001 \\
\hline Goklb & 0.62312 & 103.927 & 9.988 & 0.00001 \\
\hline Insp & 0.90277 & 26.813 & 7.074 & 0.00001 \\
\hline Flib & 0.53518 & 128.178 & 10.439 & 0.00001 \\
\hline Wc & 0.13271 & 239.162 & 11.781 & 0.00001 \\
\hline Bond & 0.92325 & 21.164 & 6.565 & 0.00001 \\
\hline Fi & 0.80534 & 53.678 & 8.567 & 0.00001 \\
\hline Source: Research $(2015)$ & & & \\
\hline
\end{tabular}

\subsubsection{Multicollinearity Test}

The possibility of strong relationship between predictor variables was checked using the correlation coefficientSpearman rho as shown in the Table AP.1 in the Appendix. The result indicates a few scores of higher than or equal to 0.8, thus reflecting lack of serious multicollinearity among variables. Thus coefficients computed were considered reliable. A second non observational method was utilized in testing for multicollinearity that is, variation inflation factor and the result for each dependent variable is as indicated in Table 5 . This result indicates NOCF slack regressed against all independent variables confirm lack of serious multicollinearity possibility. Studies have also indicated that a VIF above 20 is the one that should be categorized as challenging (Greene, 2012). Goklb and clr being above 20 are the only two challenging, thus ignored. Also a mean VIF of around 4 is not problematic (Stata, 2015). 
Table-5. Dependent Variable-NOCF Slack and all Covariates VIF Results

\begin{tabular}{l|l}
\hline Covariates & Variation Inflation Factor(VIF) \\
\hline goklb & 42.58 \\
\hline clr & 25.17 \\
\hline mp & 9.97 \\
\hline gdp & 10.59 \\
\hline cpi & 5.79 \\
\hline age & 6.07 \\
\hline flib & 5.08 \\
\hline ao & 5.38 \\
\hline w & 2.49 \\
\hline insp & 2.04 \\
\hline ms & 3.85 \\
\hline ca & 2.64 \\
\hline fi & 3.88 \\
\hline ncfma & 4.09 \\
\hline lp & 1.46 \\
\hline bond & 1.79 \\
\hline npta & 1.54 \\
\hline atech & 1.69 \\
\hline wc & 1.63 \\
\hline Mean VIF & 1.42 \\
\hline Source: Research $(2015)$ & 6.96 \\
\hline & \\
\hline
\end{tabular}

\subsubsection{Random Effects Estimation}

The Hausman-Taylor estimator method was used to confirm that none of the covariates of the panel-level models are correlated with unobserved panel-level random effects $\left(\mathrm{U}_{\mathrm{rjt}}\right)$, although some of the covariates may be associated with the unobserved individual-level random effect. The result of the estimation summary is as indicated in Table 6. The result indicates that the unobserved random effect $\delta \mu=2.5589$ greater than $\delta_{\text {error }}=.63966$,

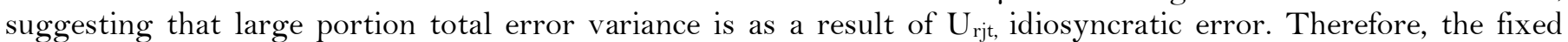
effects model and random effects model in the panel data are different $\left(\mathrm{H}_{1}\right)$ and random effects model is preferred (that is, reject $\mathrm{H}_{0}$ ). Meaning the ordinary least squares (OLS) would give inconsistent result (Stata, 2015).

Table-6. Hausmann Taylor Estimation -Slack NOCF and Covariates

\begin{tabular}{l|l}
\hline Summary of Items & Result \\
\hline Number of observations & 88 \\
\hline Number of groups & 36 \\
\hline Random effect & $\mathrm{U}_{\text {rjt }}$ iid \\
\hline Wald chi sq.(20) & 38.34 \\
\hline Prob.> chi sq & 0.0081 \\
\hline Sigma $U_{\text {rjt }}\left(\mathrm{V}_{\text {rjt }}\right)$ & 2.5589 \\
\hline Sigma erros & 0.63966 \\
\hline$R_{\text {ho }}$ & 0.9419 (fraction of value due to $\left.\mathrm{U}_{\text {rjt }}\right)$ \\
\hline Source: Research $(2015)$. &
\end{tabular}

\section{Spearman Correlation and other Key Findings}

The results of the correlation in AP.I indicate that the working capital or insolvency measure had weak negative correlation of -0.2739 with NOCF slack while women on the board at +0.562 . This correlation is not in compliance to a prior study which postulate that higher number of women on the board decreases inefficiency depending on the type of industry (Ferreira and Adams, 2009). Capital adequacy is also negatively correlated ($0.4108)$ to dependent variables of NOCF slack in line with the expectation of the agency, financial intermediation and efficiency theories (Famma, 1980; Magali and Pastory, 2013). The correlation also indicates that there is a negative relationship between log of total assets (size measure) and the NOCF output slack (or inefficiency) at 0.4108 . This finding ties well with prior study which found out an existence of positive relationship between the size of Saccos and efficiency (Magali, 2014).

\subsection{OLS Regression Correlation and Stochastic Frontier Analysis Results}

The correlation between environmental factors (prime regressors) and specific predictor variables was tested for purpose of eliminating highly correlated prime regressor(s). The results indicated are mixed with only one significant variable of compliance with regulation having $\mathrm{R}^{2}$ adjusted of 0.868 as shown in Table 7 . This lend to retention of all environmental predictor variables in the final model of this study.

This study finding in Table 8 also indicates that women on the board decrease results to increases in NOCF inefficiency although insignificant. The influence of macroeconomic variables to dependent variable of NOCF slack is also insignificant.

A predictor variable of capital adequacy had a strong positive effect on NOCF slack with coefficient of +0.4077 (p-value, 0.028). This result is contrary to efficient holding of excess funds available in form of reserves with a core objective of stability and loan issue to Sacco members. This kind of relationship may be possible where excess cash reserve is kept in banks instead of issue to members in form of loans. However, a contrary finding is seen with the relationship between NPTA with NOCF slack, that is negative, with coefficient of 2.8567(p-value 0.001). The Gamma of $1.13 \mathrm{E}-23$ is not far away from zero. Therefore, hypothesis $\mathrm{H}_{01}$ is accepted, $\mathrm{H}_{02}$ is also accepted while $\mathrm{H}_{03}$ 
is rejected, all at $95 \%$ level of confidence. The result utilized 88 observations out of a total of 368 and indicates all predictors jointly influence inefficiency given Wald Chi sq. (20) $=47.78$ (p-value 0.0005). However, the influence of control variables on NOCF slack variable is insignificant. The mean of truncated-normal distribution $\left(\mathrm{m}_{\mathrm{u}}\right)$ value of 17.6 is far from zero, thus a reflection of inability for study data to reduce to OLS regression Stata (2015).

Table-7. Regress Predictors: CPI, GDP, GOKLB, INSP, \& FLIB

\begin{tabular}{|c|c|c|c|}
\hline Dependent Variables & Adj. $\mathbf{R}^{2}$ & Prob. $>$ F & OBS. (95\% Conf.Int.) \\
\hline Age & 0.04 & 0.0011 & 368 \\
\hline $\mathbf{C a}$ & 0.01 & 0.122 & 368 \\
\hline Ta & 0.06 & 0.0001 & 368 \\
\hline Npta & 0.012 & 0.097 & 368 \\
\hline Ao & -0.014 & 1.000 & 368 \\
\hline Lp & 0.118 & 0.000 & 368 \\
\hline $\mathbf{M p}$ & -0.0005 & 0.439 & 368 \\
\hline Clr & 0.868 & 0.000 & 368 \\
\hline Atech & 0.046 & 0.0005 & 368 \\
\hline $\mathbf{W}$ & -0.010 & 0.93 & 368 \\
\hline Nefma & -0.006 & 0.699 & 368 \\
\hline Ms & 0.065 & 0.000 & 368 \\
\hline Wc & -0.0005 & 0.441 & 368 \\
\hline Bond & -0.0000 & 0.419 & 368 \\
\hline $\mathbf{F i}$ & 0.0371 & 0.0022 & 368 \\
\hline
\end{tabular}

Source: Research (2015)

Table-8. Time Varying Inefficiency Model-Regression of Net Operating Cash flows Output Slack to Predictor Variables: with Control Variables

\begin{tabular}{|c|c|c|c|c|c|c|}
\hline Observations $=88$ & & & & Wald chi & ${ }^{2}(20)=$ & 47.78 \\
\hline Log likelihood & $=0.00$ & & & Prob $>c$ & $\mathrm{hi}^{2}=$ & $0.0005^{*}$ \\
\hline Slack nocf & Coef. & Std Err. & $\mathrm{Z}$ & $\mathrm{P}>|\mathrm{z}|$ & [95\% Conf. & Interval \\
\hline $\mathrm{ca}$ & 0.407726 & 0.185043 & 2.2 & $0.028 * *$ & 0.045049 & 0.770403 \\
\hline ta & -0.03452 & 0.151889 & -0.23 & 0.82 & -0.33221 & 0.263181 \\
\hline npta & -2.85672 & 0.893375 & -3.2 & $0.001 *$ & -4.6077 & -1.10573 \\
\hline $\mathrm{mp}$ & -0.02307 & 0.131165 & -0.18 & 0.86 & -0.28014 & 0.234012 \\
\hline $\operatorname{clr}$ & 1.138453 & 1.380186 & 0.82 & 0.409 & -1.56666 & 3.843569 \\
\hline atech & 0.015717 & 0.012384 & 1.27 & 0.204 & -0.00856 & 0.039988 \\
\hline $\mathrm{w}$ & -0.23711 & 0.191488 & -1.24 & 0.216 & -0.61242 & 0.138194 \\
\hline ncfma & -0.23542 & 0.146404 & -1.61 & 0.108 & -0.52237 & 0.051525 \\
\hline gdp & 0.169315 & 0.139593 & 1.21 & 0.225 & -0.10428 & 0.442912 \\
\hline goklb & -0.39739 & 0.357685 & -1.11 & 0.267 & -1.09844 & 0.303663 \\
\hline insp & 2.304661 & 2.155104 & 1.07 & 0.285 & -1.91927 & 6.528587 \\
\hline flib & -0.78406 & 0.495805 & -1.58 & 0.114 & -1.75582 & 0.187702 \\
\hline wc & -0.04933 & 0.385944 & -0.13 & 0.898 & -0.80577 & 0.707104 \\
\hline bond & 0.011092 & 0.116058 & 0.1 & 0.924 & -0.21638 & 0.238562 \\
\hline $\mathrm{fi}$ & 0.151101 & 0.07507 & 2.01 & $0.044^{* *} *$ & 0.003967 & 0.298235 \\
\hline cons & -27.8296 & 11.68292 & -2.38 & $0.017 * *$ & -50.7277 & -4.93146 \\
\hline$/ \mathrm{mu}$ & 17.60023 & . & . & . & . & . \\
\hline /eta & 0.005481 & 0.00319 & 1.72 & 0.086 & -0.00077 & 0.011733 \\
\hline /lnsigma ${ }^{2}$ & -0.88651 & 0.00544 & -162.98 & $\mathrm{O}$ & -0.89717 & -0.87584 \\
\hline /ilgtgamma & -52.8397 &. & & . & . & . \\
\hline sigma $^{2}$ & 0.412093 & 0.002242 & & & 0.407723 & 0.41651 \\
\hline gamma & $1.13 \mathrm{E}-23$ & . & & & . & . \\
\hline sigma_u $u^{2}$ & $4.65 \mathrm{E}-24$ &. & & &. & . \\
\hline sigma_v ${ }^{2}$ & 0.412093 & . & & & . & . \\
\hline
\end{tabular}

Source: Research (2015).

Significance levels: $1 \% *, 5 \% * *$ and $10 \% * * *$

\section{Conclusion}

The general objective of this study was to establish the determinants of technical inefficiency of deposit taking Saccos in Kenya, given a net operating cash flow slack (an output inefficiency) as a dependent variable. To attain this objective, eight years panel data for 46 Saccos was analyzed by the help of data envelopment analysis and stochastic frontier model using Stata14.1 software. Therefore, the effect of five macro-economic variables, thirteen specific Saccos' predictors and two control variables against dependent variable of NOCF slack were evaluated. The dependent variable slacks (inclusive of NOCF) were determined using data envelopment analysis model in Stata14.1. It was found that 13 out of 46 Saccos scored strong technical efficiency of 1 with an average technical efficiency of 0.976 for the whole census of the study.

It was also found that specific variables influence Saccos' inefficiency given NOCF slack at $95 \%$ level of confidence. A unique result to this study is that FI specific variable is negatively correlated to dependent variable 
although regression indicates FI having a strong positive coefficient of 0.1511 (p-value, 0.044); at 95\% level of confidence, given NOCF output slack with control variables. This direction of influence is expected in an emerging sub-sector where investments are regulated and pegged at a certain percentage point.

The study further indicates that capital adequacy had significant positive effect on the NOCF slack with control variables, which is not as per the expectation unless a high incidence of cash reserves is idle in the banks instead of being loaned to members. However, the correlation between capital adequacy and NOCF slack variable was as expected at -0.4108 (negatively correlated) at $95 \%$ level of confidence.

Generally, this study indicates that Saccos' specific variables given NOCF slack variable are significant determinants of the technical inefficiency of Saccos in Kenya and that the Saccos operation is not influenced by the management influence given NOCF slack.

\section{Contribution to Theory}

This study conclusion is in line with efficiency theory which states that inefficiency of decision making unit decreases as cost reduces and banks' intermediation theory that postulates that banks' efficiency is positively related to profitability. The study further strengthens the existing prior studies on influence of capital adequacy on inefficiency or efficiency of organizations. It supports the theory of inefficiency.

Further, it can be concluded that random error (lack of management influence) is observed given NOCF slack with control variables presence as indicated by the level of Gamma. This random error aspect signify the little influence of management in Saccos, as members' active participation may override the agency problem in management of Saccos' cash flows or resources.

\subsection{Contribution to Practice and Recommendations}

It can be concluded that the identification of strong Saccos' inefficiency or efficiency over different years can be used as benchmark. Those Saccos' unique features can be adopted as the best management practices. Further, another key contribution to practice is the evidence showing that NOCF slack with control variables is a key contributor in determining non-management inefficiencies as expressed by gamma factor. The study also concludes that large size Saccos exhibit less inefficiency characteristics and therefore the regulators should encourage merger of small or medium size Saccos in the economy. The result also indicates that financial investments strongly and positively influences NOCF slack, which agrees with a short run expectation in practice, although Saccos have a core objective of issuing loans to members in both short and long run, thus limiting a possibility of the idle cash reserve. The introduction of variables such as NPTA, CA, and FI in the financial reports of Saccos and efficiency benchmarking using DEA and stochastic mechanism are important in regulation.

\subsection{Suggestions for Further Research}

The identified limitation to this study is in the area of drilling down to specific efficient Saccos using a similar approach of study to find out at micro level what actually influences the individual inefficient or efficient Saccos in the sector. It is expected that this will invite more researches in this area as the inefficiency of Saccos over the two eras remained constant. Other reasons as to why NOCF slack is not relevant in identifying management influence (agency problem) should further be researched. It may be essential to consider other predictors such as stock price real index, growth domestic product real index, income of individual members and the square of age. The comparative inefficiency study on non-deposit and deposit taking Saccos should also be studied in the future research.

\section{References}

Adams, R.B. and D. Ferreira, 2008. Women in the board room and their impact on governance and performance. Journal of Financial Economics, 94(2): 291-309.

Aigner, D.J., C.A.K. Lovell and P. Schmidt, 1977. Formulation and estimation of stochastic frontier production function model s. Journal of Econometrics, 6(1): 21-37. View at Google Scholar | View at Publisher

Banker, R.D., A. Charnes and W.W. Cooper, 1984. Some models for estimating technical and scale inefficiencies in data envelopment analysis. Management Science, 30(9): 1078-1092. View at Google Scholar | View at Publisher

Barth, M.E., W. Landsman and M. Lang, 2007. International accounting standards and accounting quality. Graduate School of Business, Stanford University, Research Paper No. 1976. Available from http:/papers.ssrn.com/sol3/papers.cfm?abstractid=688041 [Accessed 17 February 2013].

Barus, J.J., W. Muturi and P. Kibati, 2017. Effects of management efficiency on financial performance of savings and credit societies in Kenya. Journal of Strategic Management, 2(1): 92-104. View at Google Scholar

Battese, G.E. and T.J. Coelli, 1995. A model for technical inefficiency effects in a stochastic frontier production function for panel data. Empirical Economics, 20(2): 325-332. View at Google Scholar | View at Publisher

Beasley, J.E., 1996. Operation research notes: Used at imperial college. Retrieved from Http://people.brunel.ac.uk/-mastijb/jeb/or/dea.Htm [Accessed 10 February 2013].

Brealey, R.A. and S.C. Myers, 1981. Principles of corporate finance. New York: McGraw-Hill Book Company.

Brown, R., 2006. Mismanagement or mis-measurement? Pitfalls and protocols for DEA studies in financial services sector. European Journal of Research, 174(2): 1100-11 16. View at Google Scholar | View at Publisher

Brown, R. and I. O'Connor, 1999. Efficiency- bond of association and exit patterns in credit unions: Austrialian evidence. Annals of Public and Co-operative Economics, $70(1)$ : 5-23. View at Google Scholar | View at Publisher

Caprio, G., L. Laeven and R. Levine, 2003. Governance and bank valuation. Working Paper No. 10158, National Bureau of Economic Research.

Chavez, J., 2006. Impact study on the Sacco regulatory framework in Kenya. MOCDM and World Council of Credit Unions, 18.

Coelli, T., P. Rao and G. Battese, 1997. An introduction to efficiency and productivity analysis. Boston: Kluwer.

Coelli, T., P. Rao, C.J. O’Donnel and G. Battese, 2005. An introduction to efficiency and productivity analysis. New York: Spring Science and Business Media.

COK, 2010. The constitution of Kenya. 4th Schedule. Kenya Law Reports. Retrieved from www.kenyalaw.org.

Cooper, W.W., L.M. Seaford and K. Tone, 2007. Data envelopment analysis: A comprehensive text models application references and DEAsolver software, 2 nd Edn.

Cooper, W.W., L.M. Seaford and J. Zhu, 2011. Data envelopment analysis: History, models and interpretations-handbook on data envelopment analysis. International Series in Operations Research and Management Science. US: Springer, 164: 1-39.

Cummins, J.D. and H. Zi, 1998. Comparison of frontier efficiency methods: An application to the U.S life Insurance industry. Journal of producticity Analysis, 10(2): 131-152. View at Google Scholar | View at Publisher 
Emerson, S. and K. Wiren, 2005. Malawi union of savings and credit cooperatives, CGAP working group on micro insurance: Good and bad practices, case study. Malawi: MUSCO, 8

Evans, A.C., 2002. The unpaved road ahead: HIV/AIDS and microfinance. An explanation of Kenya credit unions (Saccos). Research Monograph Series No. 21 , Winconsin, Woccu.

Famma, 1980. Agency problems and theory of the firms. Journal of Political Economy, 88(2): 288-307. View at Google Scholar

Ferreira, D. and R.B. Adams, 2009. Women in the boardroom and their impact on governance and performance. Journal of Finance of Finance and Economics, 94(2): 291-309. View at Google Scholar | View at Publisher

Gompers, P., J. Ishii and A. Metrick, 2003. Corporate governance and equity prices. Quarterly Journal of Economics, 118(1): 107-155. View at Google Scholar

Greene, W.H., 2012. Econometric analysis. 7th Edn., New York: Pearson Education, Inc.

Healy, R.K., 1988. How will performance evaluation perform. Journal of Portfolio Management: 15-19.

Higgs, D., 2003. Review of the role and effectiveness of non-executive directors. On-line. Retrieved from www.dti.gov.uk/cld/non-execsreview.

IMF, 2012. International monetary fund, world economic outlook update.

IMF, 2014. International monetary fund, world economic outlook database. Retrieved from http://www.imf.org/external/pubs/ft/weo/2012/02/weodata/weorept.aspx [Accessed November 4, 2014$].$

Johnson, S. and M. Nino-Zarazua, 2008. A report prepared for the decentralized financial services project. Kenya and Financial Sector Deepening (FSD), Kenya. Centre for Development Studies, Univeristy of Bath.

Jondrow, J., C.A.K. Lovell, I.S. Materov and P. Schmidt, 1982. On the estimation of technical inefficiency in the stochastic frontier production function model. Journal of Econometric, 19(2-3): 233-238. View at Google Scholar | View at Publisher

Kamau, A.W., 2011. Intermediation efficiency and productivity of the banking sector in Kenya, Interdisciplinary. Journal of Research in Business, 1(9): 12-26.

Karanja, J.N., 2013. The relationship between size and cost efficiency of Saccos with front office service activity in Kenya. Unpublished MSc. Finance Project, Univeristy of Nairobi.

Khainga, D., 2014. African growth initiative working paper- Divisia Monetary Aggregates and Demand for Money in Kenya.

Kipesha, E.F., 2012. Efficiency of microfinance institutions in East Africa: A data of envelopment analysis. European Journal of Business and Management, 4(17): 77-88. View at Google Scholar

Kivuvo, M.R. and T. Olweny, 2014. Financial performance analysis of Kenya's SACCO sector using the Altiman Z score model of corporate bankruptcy. International Journal of Business and Social Science, 5(9). View at Google Scholar

Magali, J.J., 2014. Variables for modelling Saccos in Tanzania. Asian Journal of Finance and Accounting, 6(1): 198-215. View at Google Scholar 1 View at Publisher

Magali, J.J. and D. Pastory, 2013. Technical efficiency of rural savings and credits co-operatives in Tanzania. A DEA approach. International Journal of Management Sciences and Busienss Research, 2(12): 49-61.

Marwa, N. and M. Aziakpono, 2015. Technical and scale efficiency of savings and credit cooperatives: Evidence from Tanzania, Univeristy of Stellenbosch Businsss school, South Africa. ERSA, Working Paper No.5 10.

Mirie, M., 2014. The influence of members' income and conduct of Saccos in the relationship between characteristics and efficiency of Saccos in Kenya. PhD Thesis Presented at University of Nairobi.

MOCDM, 2013. Ministry of Industry, Trade and Co-operatives. Achievements of the Ministry July 2013-2014. Retrieved from http://www.industrialization.go.ke/index.php.

Moffat, B.D., 2008. Efficiency and productivity in Botswana's financial institutions. PhD Thesis Presented at University of Wollongong.

Njagi, G.M., E.M. Kimani and N.N. Ngugi, 2013. The impact of front office Sacco activity on Sacco performance in Kenya. A case study of Meru South and Maara district in Tharaka Nithi County in Kenya. Global Advanced Research Journal of Management and Business Studies, 2(5): 285-290. View at Google Scholar

Nyambere, F.K., 2013. Effect of credit risk management on financial performance of deposit taking savings and credit co-operative societies in Kenya. Unpublished MBA Project, University of Nairobi.

Ogebe, J.O., P. Ojah and K. Alewi, 2013. The impact of capital structure on firm performance in Nigeria. St. Augustine College of Educations. MPRA Paper No. 45986.

Okibo, B. and J.M. Karagu, 2014. Financial factors influencing performance of savings and credit co-operative organization in Kenya. International Journal of Academic Research in Accounting, Finance and Management Sciences, 4(2): 295-206. View at Google Scholar

Olando, C.O., A. Jagongo and Martin, 2012. Financial practice as a determinant of growth of savings and credit co-operative societies wealth. International Journal of Business and Social Science, 3(24): 204-2 19. View at Google Scholar

Ongore, V.O. and B.G. Kusa, 2013. Determinants of financial performance of commercial banks in Kenya. International Journal of Economics and Financial Services, 3(1): 237-252. View at Google Scholar

Ozcan, Y.A., 2008. Health care benchmarking and performance evaluation. An assessment using data envelopment analyis. Retrieved from HttP://.springer.com/978-0-387-75447-5 [Accessed 17 February 2013].

Pagano, Hughes, Lang and Moon, 1997. Using the frontier methods in a non-structural approach. A Proxy for Agency Cost X-Inefficiency.

Pascoe, S., J.E. Kirkley, D. Greboral and M.C.J. Paul, 2003. FAO, measuring and assessing capacity in fisheries. FAO Fisheries Technical Paper No.433/2.

Petrie, R., 2002. Rwanda credit unions member and non-member survey. Woccu Inc. Research Monorgraph Series No. 20.

Reis, R. and N.G. Mankiw, 2001. Sticky information and versus sticky prices: A proposal to replace new Keynesiam Philips curve. Proceedings, Federal Reserve Bank of San Francisco.

Research, 2015. Research data.

SASRA, 2011. The sacco society regulatory authority, Kenya. Sacco Supervision Report for Deposit Taking Saccos, year 2011.

SASRA, 2013. The SASRA leaders' Forum. [Accessed 30 October, 2014].

SSA, 2008. Sacco Societies Act, 2008. Kenya Gazette No.14. Revised in 2012. [Accessed 18 February, 2015].

SSR, 2010. Sacco Societies Regulation,2010. Kenya Gazette Supplement No.39. [Accessed 11 March, 2015].

Stata, 2015. Statistics/data analysis 14.1. Statacorp LP. Retrieved from http://www.stata.com.

Tesfamariam, K., H. Tesfay and A. Tesfay, 2013. Relative efficiency of rural saving and credit co-operatives: An application of date envelopment analyisis. International Journal of Co-perative Studies, 2(1): 16-25.

Wanyama, F.O., 2009. Surviving liberalization: The cooperative movement in Kenya. ILO; the Co-operative Facilty for Africa Working Paper No.10.

Wanyama, F.O., P. Develtere and I. Pollet, 2009. Reinventing the wheel? African co-operative in a liberalized economic environment. The Co-operative Facilities for Africa Working Paper No. 1.

Woccu, 2009. World council of credit unions, 2009 survey. Retrieved from www.woccu.org/functions/viewdocument.php?id=2009 [Accessed 10 February 2013].

World Bank, 2014. GDP deflator base year per country. Retrieved from http://data.worldbank.org/indicator/NY.GDP.DEFL.ZS $[$ Accessed 4 November, 20147.

Zvi, G., 1998. Credit co-operatives and co-operative banks. Co-operative Dialogue, 8(1): 31-39. 


\section{Appendixes:}

Table-AP.1. Predictor Variables Correlation Coefficient

\begin{tabular}{|c|c|c|c|c|c|c|c|c|c|}
\hline & & Correlation & Coefficient & & & & & & \\
\hline \multirow[t]{2}{*}{ Spearman, } & (rho) & & & & & & & & \\
\hline & age & $\mathrm{ca}$ & ta & npta & ao & lp & & & \\
\hline age & 1 & & & & & & & & \\
\hline $\mathrm{ca}$ & 0.8186 & 1 & & & & & & & \\
\hline ta & 0.7933 & 0.6833 & 1 & & & & & & \\
\hline npta & 0.5654 & 0.45 & 0.5667 & 1 & & & & & \\
\hline ao & 0.5241 & 0.1035 & 0.6211 & 0.414 & 1 & & & & \\
\hline lp & 0.1772 & 0.0667 & -0.4167 & -0.6 & -0.5175 & 1 & & & \\
\hline $\mathrm{mp}$ & 0.3967 & 0.25 & 0.8167 & 0.3833 & 0.6211 & -0.65 & & & \\
\hline $\operatorname{clr}$ & 0.0957 & 0.1632 & 0.0344 & -0.1288 & 0.0533 & 0.1546 & & & \\
\hline atech & 0.5466 & 0.3598 & 0.3096 & 0.6109 & 0.5717 & -0.5272 & & & \\
\hline $\mathrm{w}$ & 0.4979 & 0.2907 & 0.4189 & 0.1966 & 0.7434 & 0.094 & & & \\
\hline ncfma & 0.3713 & -0.0333 & 0.5 & 0.2833 & 0.5175 & -0.7333 & & & \\
\hline $\mathrm{ms}$ & 0.5739 & 0.65 & 0.8667 & 0.2667 & 0.414 & -0.0833 & & & \\
\hline cpi & 0.3463 & -0.1624 & 0.0171 & $\mathrm{O}$ & -0.3717 & -0.3762 & & & \\
\hline $\operatorname{gdp}$ & 0.4762 & 0.2821 & 0.1197 & -0.0171 & 0.4779 & 0.342 & & & \\
\hline goklb & 0.7966 & -0.5215 & -0.3591 & -0.342 & -0.4779 & -0.1026 & & & \\
\hline insp & 0.7793 & -0.6754 & -0.4788 & -0.3762 & -0.2655 & 0.1026 & & & \\
\hline flib & 0.8226 & 0.4873 & 0.4446 & 0.3249 & 0.5841 & 0.0342 & & & \\
\hline wc & 0.9283 & 0.9333 & 0.75 & 0.5667 & 0.414 & -0.0833 & & & \\
\hline bond & 0.8405 & -0.6299 & -0.5533 & -0.5193 & -0.3701 & 0.4086 & & & \\
\hline fi & 0.6583 & 0.7 & 0.9167 & 0.3833 & 0.414 & -0.1667 & & & \\
\hline Slack tr & -0.3467 & -0.4108 & -0.4108 & -0.4108 & 0.189 & 0.4108 & & & \\
\hline Slack lm & -0.5547 & -0.2739 & -0.5477 & $\mathrm{O}$ & -0.6614 & 0.1369 & & & \\
\hline Slack nocf & -0.3467 & -0.4108 & -0.4108 & -0.4108 & 0.189 & 0.4108 & & & \\
\hline \multirow[t]{2}{*}{ Slack div } & -0.2017 & -0.2988 & -0.5179 & 0.1594 & -0.3093 & -0.1295 & & & \\
\hline & $\mathrm{mp}$ & $\mathrm{Clr}$ & atech & $\mathrm{W}$ & ncfma & $\mathrm{ms}$ & cpi & gdp & goklb \\
\hline $\mathrm{mp}$ & 1 & & & & & & & & \\
\hline $\mathrm{clr}$ & 0.2147 & 1 & & & & & & & \\
\hline atech & 0.1506 & 0.0561 & 1 & & & & & & \\
\hline $\mathrm{W}$ & 0.1453 & 0.1542 & 0.4507 & 1 & & & & & \\
\hline ncfma & 0.6833 & -0.3177 & 0.2176 & -0.1111 & 1 & & & & \\
\hline $\mathrm{ms}$ & 0.6833 & 0.1889 & 0.0251 & 0.436 & 0.1333 & 1 & & & \\
\hline cpi & 0.2992 & -0.163 & -0.3391 & -0.7193 & 0.2137 & 0.1197 & 1 & & \\
\hline $\operatorname{gdp}$ & -0.1453 & 0.2952 & 0.4164 & 0.7807 & -0.1453 & 0.0513 & $\begin{array}{l}- \\
0.9474\end{array}$ & 1 & \\
\hline goklb & 0.1111 & 0.2687 & -0.5881 & -0.6842 & -0.0769 & -0.1881 & 0.6842 & -0.7368 & 1 \\
\hline insp & -0.1111 & 0.2247 & -0.5538 & -0.2982 & -0.1624 & -0.4104 & 0.0526 & -0.2456 & 0.7193 \\
\hline flib & 0.0256 & -0.2687 & 0.5624 & 0.7105 & 0.1966 & 0.2736 & $\begin{array}{l}- \\
0.6316\end{array}$ & -0.7193 & 0.9825 \\
\hline wc & 0.3167 & 0.1288 & 0.5941 & 0.5386 & 0.1 & 0.6167 & $\begin{array}{l}- \\
0.3762\end{array}$ & -0.4959 & 0.7182 \\
\hline bond & -0.2894 & 0.2105 & -0.671 & -0.1528 & -0.5703 & -0.1788 & 0.2183 & -0.3057 & 0.655 \\
\hline fi & 0.7167 & 0.1116 & 0.0753 & 0.3676 & 0.2333 & 0.9833 & 0.1624 & -0.0085 & 0.2308 \\
\hline Slack tr & -0.4108 & 0.1411 & $\mathrm{O}$ & 0.562 & -0.5477 & -0.1369 & $\begin{array}{l}- \\
0.4215\end{array}$ & 0.4215 & $\begin{array}{l}- \\
0.1405\end{array}$ \\
\hline Slack lm & -0.5477 & -0.2117 & -0.275 & -0.4917 & -0.4108 & -0.5477 & 0.1405 & -0.4215 & 0.4215 \\
\hline Slack nocf & -0.4108 & 0.1411 & $\mathrm{O}$ & 0.562 & -0.5477 & -0.1369 & $\begin{array}{l}- \\
0.4215\end{array}$ & 0.4215 & $\begin{array}{l}- \\
0.1405\end{array}$ \\
\hline \multirow[t]{2}{*}{ Slack div } & -0.5179 & -0.3746 & 0.18 & -0.3934 & 0.0697 & -0.8367 & $\begin{array}{l}- \\
0.1737\end{array}$ & -0.0511 & $\begin{array}{l}- \\
0.0307\end{array}$ \\
\hline & insp & flib & wc & bond & $\mathrm{Fi}$ & slacktr & $\begin{array}{l}\text { Slack } \\
\operatorname{lm}\end{array}$ & $\begin{array}{l}\text { slackno } \\
\text { cf }\end{array}$ & $\begin{array}{l}\text { slackd } \\
\text { iv }\end{array}$ \\
\hline insp & 1 & & & & & & & & \\
\hline flib & -0.7368 & 1 & & & & & & & \\
\hline wc & -0.7182 & 0.7011 & 1 & & & & & & \\
\hline bond & 0.69 & -0.655 & -0.7406 & 1 & & & & & \\
\hline fi & -0.4873 & 0.3163 & 0.6667 & -0.2979 & 1 & & & & \\
\hline Slack tr & 0.1405 & 0.1405 & -0.2739 & 0.5595 & -0.2739 & 1 & & & \\
\hline Slack lm & 0.562 & -0.562 & -0.4108 & 0.3497 & -0.5477 & -0.125 & 1 & & \\
\hline Slack nocf & 0.1405 & 0.1405 & -0.2739 & 0.5595 & -0.2739 & 1 & -0.125 & 1 & \\
\hline Slack div & 0.2453 & -0.0818 & -0.249 & -0.2086 & -0.757 & -0.2455 & 0.6547 & -0.2455 & 1 \\
\hline
\end{tabular}

Source: Research (2015)

AP.II: Operational Definition of Terms

Common Bond Size: Number of entities through which Sacco members contribute funds (or share common interest) to the Sacco where they own shares and deposits (Research, 2015).

Cost Inefficiency: Saccos' excessive cost relative to the frontier. It is the difference between a benchmark and achieved performance i.e. x-efficiency (or proxy of agency costs) (Pagano et al., 1997).

Credit and Savings Co-operatives: Saccos relying too much on external source of funds than share capital, reserves and member deposits (Research, 2015). 
DEA: Data envelopment analysis

Earnings Management: In an organization when a governor fidgets with accounting numbers in order to report higher profits and subsequently pay high dividends is what is known as earnings management (Barth et al., 2007).

Financial liberalization (FL): Measured by monetary aggregate (money supply or M3XT) to GDP (Cooper et al., 2007; Research, 2015).

GOK Net Lending/Borrowing as \% of GDP (GOKLB): It measures the extent government is either putting financial resources at the disposal of other sectors in the economy (World Bank, 2014). This is a proxy for financial depth and innovative activities in Kenya.

Inefficiency (Management Inefficiency): The proportion by which the observed outcome or goal attainment fall short of optimum level. It is represented by one-sided error term $\left(U_{r j t}\right)$ with a non-zero mean. $U_{r j t}$ is normally assumed to be truncated-normal (Aigner et al., 1977; Greene, 2012).

Inflation Consumer Price Index (CPI): Measures changes in prices of goods and services that households consume that affect the consumers' real purchasing power and their welfare in Kenya. CPI and GDP deflator are cross-correlated (Reis and Mankiw, 2001). A proxy for market condition.

Interest Spread (INSP): Average lending rate minus average borrowing rate (World Bank, 2014). A proxy for risk pricing in Kenya

Liberalization Period (LP): Era of economic reforms specifically 1980s-1990s and after (Research, 2015).

Money Supply (M3XT): M3XT is the currency in circulation measure in Kenya that is all-encompassing (Khainga, 2014).

Post-Liberalization: After amendment of Co-operatives Act, 2004 (Research, 2015).

Pre-Regulation Period: 2010 and before SASRA time-from 2007 (Research, 2015).

Regulation Period: During SASRA from 2011 and after - to 2014 (Research, 2015).

SASRA License: Saccos operating FOSA were required by Saccos Societies Regulation 2010 of the Sacco Societies Act, 2008 to have applied for license by 17 June 2011 (SSA, 2008).

Slack: Amount by which either an output or input fail to attain the optimal efficiency. It is an equivalent of inefficiency level (Cooper et al., 2007).

Specific Predictor Variables: Independent study variables (variance regressors) that exclude the macro-economic independent variables (Research, 2015).

Stochastic Frontier Analysis (SFA): A parametric method that can test hypotheses and can accommodate single output with multiple inputs. It also uses maximum likelihood econometric estimation and decomposes the error term (e) into two components (Aigner et al., 1977).

Technically Efficient: A firm operates on the frontier of the production technology (Coelli et al., 1997).

Urban Areas: Town or Municipality area. The Urban Areas are separated from Cities according to Kenya Urban Areas and Cities Act, No.13 of 2011, revised in 2015 (Research, 2015). 